\title{
An Issue of "Who Sees" the Fictional World: Teaching the Conceptual Evolution of Focalization
}

\author{
Shang Guanghui \\ College of Foreign Studies, Jiaxing University, Jiaxing, China \\ Email address: \\ dillonzhushang@163.com \\ To cite this article: \\ Shang Guanghui. An Issue of "Who Sees" the Fictional World: Teaching the Conceptual Evolution of Focalization. International Journal of \\ Literature and Arts. Vol. 9, No. 1, 2021, pp. 34-39. doi: 10.11648/j.ijla.20210901.16
}

Received: February 6, 2021; Accepted: February 18, 2021; Published: February 27, 2021

\begin{abstract}
Narratology constitutes a vital component of literary criticism and theory. A prime goal of narratology teaching is to build a systematic conceptual framework of key narrative concepts for students. A good command of the core concepts of narrative theory ensures profound narratological textual criticism. Taking focalization as a case study for Chinese college students, this paper analyzes the evolution and current state of focalization theory with the aim of helping them to acquire a systematic conceptual framework of focalization theory. This paper adopts both synchronic and diachronic approaches to examine the conceptual evolution of focalization, focusing on the early exploration of focalization, the focalization study in classical and postclassical narratology, and the analysis of nonhuman focalization. Focalization is an issue of "who sees" which is often conflated with the issue of "who speaks" in the early stage of its conceptual evolution. Genette has made a distinction between them, and scholars of classical narratology developed variegated focalization theories. Postclassical narratology made major improvements, emphasizing readers' reception and the context of focalization. Nonhuman focalization, a distinctive dimension of focalization theory, also counts as an important interpretative perspective concerning focalization for students. An elaborate discussion of the conceptual evolution of focalization seeks to reveal to students a multi-dimensional conception of focalization as a way to enhance their ability to perform a narratological reading of literary texts.
\end{abstract}

Keywords: Narratology Teaching, Focalization Theory, Conceptual Evolution

\section{Introduction}

Students taking narratology courses have some knowledge of narrative theory, and able to give a narratological reading of literary texts. Many narrative concepts Chinese college students learn in their narratology courses, including story and discourse, narrative situations, time, and space, are geared toward some primary narratological textual criticism and practice, but they still need to know the evolution and current state of these key narrative concepts to ensure that they can gain a systematic conception of narrative theory. A systematic study of these concepts is core to profound narratological textual criticism and practice. The concept of focalization marked by a complex conceptual development is an appropriate case study for Chinese college students who are unable to assimilate the theoretic evolvement of this concept and fail to acquire a systematic conceptual framework of focalization theory. They tend to neglect the early theoretic exploration of focalization and fail to understand the key focalization theories of postclassical narratology.

\section{The Issue of "Who Sees" or "Who Speaks": The Early Exploration of Focalization}

It is not hard for students to dig up the first scholar who proposes the concept of focalization. Genette argues in Narrative Discourse (1980), a seminal narratological work, that focalization serves to clear the confusion between what he calls "mood and voice, a confusion between the question who is the character whose point of view orients the narrative perspective? and the very different question who is the narrator? - or, more simply, the question who sees? and the question who speaks?" [1]. For him, focalization, a "slightly more abstract term," is similar to point of view which has "specifically visual connotations" [1]. But I find that most students in my class are unable to expound on the theoretic 
exploration of focalization before Genette has distinguished between focalization and narration. Thus, I reveal to them the following scholars' ideas that contribute to the theory of focalization.

Genette finds that before he formulated the concept of focalization, scholars did not draw a distinction between focalization and voice, or point of view and narration. Cleanth Brooks and Robert Penn Warren, for example, develop a typology of point of view that is mixed with voice [2]. They determine four types of points of view which are summarized in the following figure:

\begin{tabular}{lcc}
\hline & Internal analysis of events & External observation of events \\
\hline $\begin{array}{l}\text { First person: a narrator } \\
\text { is a character. }\end{array}$ & $\begin{array}{l}\text { 1. A protagonist tells his or } \\
\text { her own story. }\end{array}$ & $\begin{array}{c}\text { 2. A minor character tells } \\
\text { a protagonist's story. }\end{array}$ \\
Third person: a narrator & $\begin{array}{c}\text { 4. An omniscient narrator tells } \\
\text { the story, entering other }\end{array}$ & 3. An author tells the \\
is not a character. & characters' minds. & story as an observer, \\
\end{tabular}

Figure 1. A typology of points of view from Cleanth Brooks and Robert Penn Warren, Understanding Fiction (3 ${ }^{\text {rd }}$ ed., Englewood Cliffs, New Jersey: Prentice-Hall, Inc., 1979; 174).

As the figure illustrates, the vertical demarcation is concerned with point of view as the two adjectives internal and external imply people's vision or perspective, while the horizontal demarcation obviously highlights voice as a narrator is one who speaks in narratives.

The same problem applies to Norman Friedman who has proposed eight types of points of view: editorial omniscience, neutral omniscience, "I" as witness, "I" as protagonist, multiple selective omniscience, selective omniscience, the dramatic mode, and the camera. Neutral omniscience features the absence of authorial intrusions; on the contrary, editorial omniscience means that "it is the author's voice which dominates the material, speaking frequently as 'I' or "we"" [3]. "I" as witness and "I" as protagonist are two forms of the first person narration; they differ in that the former tells others' stories, while the latter tells his own story. While multiple selective omniscience is equivalent to multiple points of view, selective omniscience corresponds to a single point of view. The dramatic mode and the camera are two modes of purely objective showing. It can be seen from the above comparisons that half of the eight types of points of view highlight voice rather than point of view. Obviously, omniscience in the first two types is a matter of the authorial voice, and the third and fourth types foreground the first person narrator. Only multiple selective omniscience and selective omniscience in this taxonomy are closely related to point of view. In a similar vein, F. K. Stanzel has integrated mood and voice into a single concept of "narrative situation," ascertaining three narrative situations: the first-person narrative situation in which the narrator is one of characters in the story, the authorial narrative situation in which the narrator and other characters exist in different levels, the figural narrative situation in which readers see events and characters through the eyes of a reflectorcharacter [4]. The theory of narrative situation, as Stanzel argues, includes three parameters: perspective, mode, and person, and different narrative situations foreground different parameters. The first-person narrative situation gives prominence to the first person as a character, while the external perspective stands out in the authorial narrative situation. The reflector mode is the most noticeable parameter in the figural narrative situation.

Despite the fact that numerous scholars confuse point of view and voice, there are scholars who properly deal with them. Jean Pouillon, for instance, has expounded solely on "vision" which, in Genette's opinion, is basically similar to point of view [1]. Pouillon proposes three kinds of visions: vision from behind, vision within, vision from without [1]. Accordingly, Todorov develops three formulas to represent them. Vision from behind is represented by the formula: Narrator $>$ Character which means that the narrator can tell things that characters don't know; vision within corresponds to the formula: Narrator $=$ Character which means the narrator can only tell what characters know; vision from without is symbolized by the formula: Narrator < Character which means characters know more than the narrator knows [1]. Evidently, Pouillon's typology of vision and Todorov's three formulas focus on point view and voice respectively. Following Pouillon's typology, Genette proposes three kinds of focalization: zero focalization, internal focalization, and external focalization [1]. Zero focalization is characteristic of classical narratives with omniscient narrators. Internal focalization refers to narratives with points of view, or reflectors, and a story can have a fixed reflector, variable reflectors or multiple reflectors. External focalization is found in narratives of objective showing such as "Hills like White Elephants" (1927).

One thing that needs to be pointed out is that Genette is not the first to stress the issue of focalization. In both literary writing and criticism, Henry James is fascinated "by the problem of finding a 'centre,' a 'focus,' for his stories," and the problem is to a large degree resolved by "considering how the narrative vehicle could be limited by framing the action inside the consciousness of one of the characters within the 
plot itself' [3]. Taking his inspiration from James's novelistic practice and theory, Percy Lubbock distinguishes between showing which dramatizes events, and telling which describes events, arguing that showing is a better fiction craft: "other things being equal, the more dramatic way is better than the less. It is indirect, as a method; but it places the thing itself in view, instead of recalling and reflecting and picturing it" [5]. The major method to achieve showing is "to have the story told as if by a character in the story, but told in the third person" [3]. In this way, readers perceive events in the story as they filter through the consciousness of a certain character, yet perceive them directly as they impinge upon "that consciousness, thus avoiding that removal to a distance necessitated by retrospective first-person narration" [3].

\section{The Confirmation of the Issue of "Who Sees": The Focalization of Classical Narratology}

In classical narratology, numerous scholars contrived to develop their distinct theories of focalization, most of which are familiar to students. But it is quite necessary for them to discriminate between these theories and to assimilate the fact that these theories mostly develop from Genette's focalization theory. To further acquit them with these theories, I offer a detailed account of them with specific examples. In Narratology: Introduction to the Theory of Narrative (1997), Mieke Bal determines two important aspects of focalization: the focalized object, and the focalizor. The focalized object refers to "objects, landscapes, events, in short all the elements" which "are focalized, either by an EF or by a CF" [6]. The focalizor is "the subject of focalization" or "the point from which the elements are viewed" [6]. CF (character-bound focalizor) and EF (external focalizor) are two related terms that Bal proposes. A CF is an internal focalizor who is also one of characters, while an EF is an external focalizor who is not character-bound [6]. The shift from EF to CF is a phenomenon that can be found in quite a number of novels. For example, in The Brief Wondrous Life of Oscar Wao (2007), Yunior, one of the focalizors, serves as an EF in the first fours chapters. Readers don't know his name until chapter four in which he turns out be a character who is a close friend of the novel's protagonist, Oscar Wao.

In Narrative Fiction: Contemporary Poetics (2002), Rimmon-Kenan distinguishes between internal and external focalization [7]. It can be found that internal focalization in Rimmon-Kenan typology is similar to that in Genette's typology, and both external focalization in Rimmon-Kenan typology and zero focalization in Genette's typology are tied to classical omniscient narratives. Rimmon-Kenan also argues that external focalization can appear in first-person narratives as well, "either when the temporal and psychological distance between narrator and character is minimal $[\ldots]$ or when the perception through which the story is rendered is that of the narrating self rather than that of the experiencing self" [7]. Obviously, these phenomena aren't cases of zero focalization proposed by Genette as it only refers to "narrative with an omniscient narrator" [8].

Rimmon-Kenan also determines three facets of focalization: the perceptual facet, the psychological facet, and the ideological facet. The two parameters of the perceptual facet are space and time. As for space, an external focalizor can have a panoramic view of the fictional world, as evidenced by omniscient narrators in classical narratives; an internal focalizor can only have a limited view of the story, as witnessed by Nick Caraway in The Great Gatsby (1925). As for time, an external focalizor can present scenes arising at any time, past, present or future. But an internal focalizor can only show readers past scenes. The two parameters of the psychological facet are cognition and emotion. As for cognition, an external focalizor has unlimited knowledge about the story, as is exemplified by the narrator focalizor in Fielding's Tom Jones (1749); an internal focalizor has limited knowledge about the fictional world, as exemplified by Stephen Dedalus in A Portrait of the Artist as a Young Man (1916). With respect to emotion, the focalized object of external focalization is objectively or neutrally shown, while the focalized object of internal focalization is subjectively represented. A case in point is Emma's presentation of a garden scene in Madame Bovary (1856). In Emma's eyes, "No birds were singing, everything seemed asleep, the straw-covered espaliers and the vine like a great sick snake coiled under the coping of the wall where, if you went up close, you could see woodlice crawling on their many feet" [9]. Evidently, for Emma, one of internal focalizors of the novel, the garden is lifeless. The ideological facet of a text is usually presented through the perspective of the main focalizor, usually the narrator-focalizor. In many cases, a story showcases a multiplicity of mutually opposing ideologies represented by different character focalizors, therefore sparking off a polyphonic reading of it.

Point of view, according to Seymour Chatman, includes three senses: 1. original sense: through somebody's eyes, or perception; 2. metaphoric sense: through somebody's world outlook, or ideology; 3. transferred sense: from somebody's interest, or wellbeing. Accord to the three senses, he proposes perceptual point of view, conceptual point of view, and interest point of view [10]. A narrative text usually features a juxtaposition or combination of such three points of view. An example is retrospective narrative. The experiencing-I, one of focalizors, presents his past-self objectively. The narrating-I, another focalizor, is much more intelligent and experienced; therefore, what he narrates often includes opinions or attitudes which reflect his ideology. In Reading Narrative Fiction (1993), he details two forms of points of view: character's filter and narrator's slant. Filter is an illusion of characters' mental life, and it changes their consciousness into a "screen" through which readers get to know their personalities, events or the events' influence on them [11]. Narrator's slant refers to the narrator's opinion of events or characters [11]. While "filter" is a neutral presentation, slant shows much subjectivity and bias. The filter-character is usually not the narrator, but there are cases in which the filter-character and the narrator are the same figure. Chatman calls this 
phenomenon "internal narration," another name for retrospective narrative. Even in such texts, there is often a time lag enabling readers to separate the narrator I ("now") from the filter-character I ("back then") [11]. Obviously, both Rimmon-Kenan and Chatman have ascertained the perceptual and ideological aspects of point of view, which lays foundation for the development of focalization theory in postclassical narratology attaching great importance to ideology and context.

\section{The Improvement of the Issue of "Who Sees": The Focalization of Postclassical Narratology}

In postclassical narratology, focalization is examined through an interdisciplinary approach, focusing more on context and reader's reception than form and structure, as is clearly shown by Manfred Jahn's "windows of focalization" and David Herman's "hypothetical focalization" which are unfamiliar to students used to interpreting narrative texts from the perspective of the focalization theories of classic narratology. In this section, I elaborate on the two focalization theories to help them to attain a more systematic understanding of focalization, and inspire them to analyze narrative texts from both classical and postclassical perspectives.

Inspired by Henry James's novelistic practice of widows of "house of fiction," the theory of cognitive interfaces proposed by Ray Jackendoff, aesthetic illusion discussed by Werner Wolf, and Mark Johnson's exploration of natural metaphors, Manfred Jahn proposes "windows of focalization" through which both narrators and readers perceive and imagine the fictional world. He relates the issue of "seeing" to what Henry James calls "house of fiction" and its windows, regarding the window metaphor of fiction as "a core model of focalization" [12]. Seers facing "house of fiction" and its windows are assumed to be extradiegetic narrators. As extradiegetic perceivers, they can imagine what is going on in the fictional world in front of "windows." But they can perceive the fictional world through millions of windows of "house of fiction" as well; the same activity also goes to narratees or readers. In many of Henry James's novels, authorial narrators, together with readers, observe stories as they are unfolded in reflector-characters' consciousness. Reflector characters can see the events or objects from within the fictional world, and their consciousness mirrors the fictional world, functioning as windows. In "More Aspects of Focalization: Refinements and Applications," he polishes his theory of "windows of focalization" by proposing four types of focalization, as illustrated in the figure below:

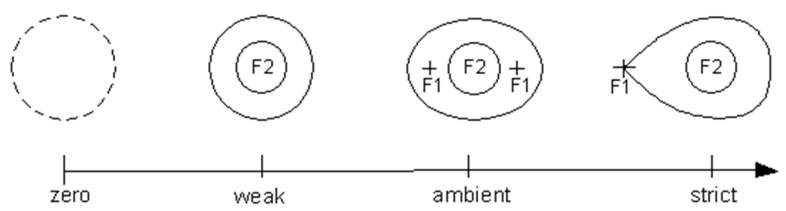

Figure 2. A scale of focalization from Manfred Jahn, "More Aspects of Focalization: Refinements and Applications" (Jahn: Homepage. N. p., 4 Mar. 2000. Web. 18 February 2016).
In the figure, F1 represents a focal point or focalizor, and F2 represents the focalized. In strict focalization, F2 is viewed from a fixed F1. In ambient focalization, F2 is viewed by two or more F1s; ambient focalization is free of "specific time-place anchoring" and allows "a mobile, summary, or communal point of view" [13]. In weak focalization, F1 vanishes, with only F2 left behind. In zero focalization, both F1 and F2 vanish. Strict and ambient focalizations prevail in narratives. Weak focalization is used to present sheer facts. Zero focalization features "a random collection of narrative sentences" as there are no focal point, the focalized object, and temporal-spatial arrangement in it [13]. Shifting patterns of "windows of focalization" are elaborated as well in this paper. Shifts between different reflectors and shifts in time and space are two basic shifting patterns. "Windows of focalization" can also shift from the representation of pure perception to the representation of imagination, dreams, and hallucination. Window shifts usually go hand in hand with deictic shifts of person, space or time. From the foregoing analysis, we can see that for all his concentration on formal and structural features of narrative texts in his analysis of focalization, he tries to draw on readers' reception theory and cognitive linguistics to formulate a new theory of focalization. His endeavor best illustrates "an interdisciplinary, integrative, and non-dichotomous approach towards focalization" in postclassical narratology [12].

"Hypothetical focalization" involves "the use of hypotheses, framed by the narrator or a character, about what might be or have been seen or perceived," and is predicated on the assumption that there is someone who will adopt "the requisite perspective on the situations and events at issue" [14]. Hypothetical focalization falls into direct and indirect HF. Direct HF refers to texts that clearly foreground the existence of "a hypothetical witness," while indirect HF refers to texts that require us to infer the existence of a hypothetical witness. Both direct and indirect HF can be ascertained with specific grammatical or lexical indicators. Just consider a sentence from Edgar Allan Poe's "The Fall of the House of Usher" (1839): "Perhaps the eye of a scrutinizing observer might have discovered a barely perceptible fissure" [15]. Lexically, the word "observer" denotes the existence of a witness observing the house of Usher. Grammatically, the modal verb "might" suggests the witness's uncertainty about the state of affairs. Indirect HF can be exemplified by a sentence from Stephen Crane's "The Open Boat" (1897): "Viewed from a balcony, the whole thing would, doubtless, have been weirdly picturesque" [16]. The past participle phrase "viewed from a balcony" is highly suggestive of the existence of an observer on the scene; in addition, the modal verb "would" and the adverb "doubtless" indicate that the scene we see is probably focalized through an anonymous witness in the fictional world. It can be seen from the above analysis that Herman also exploits reader-oriented and linguistic theory to develop a theory of "Hypothetical focalization" as Jahn has done to establish the theory of "windows of focalization." 


\section{A New Perspective on the Issue of "Who Sees": Texts of Nonhuman Focalization}

In both classical narratology and postclassical narratology, as a general rule, focalization presupposes that a focalizor is usually a human being, but cases of animal focalization are quite common in literary history. Animal focalization counts as an important interpretative perspective. It falls into the category of unnatural narrative denoting represented events that "do not copy or extend but rather violate some of the laws of everyday existence" [17]. In the texts of animal focalization, the animal focalizors possess human intelligence and think as humans do, which obviously deviates from the real world physical laws. Animal focalization allows students to see a distinctive dimension of focalization theory, and is meant to inspire them to interpret texts of nonhuman focalization from the perspective of focalization. The following texts and analysis are intended to illustrate animal focalization for them.

In "Beyond the Bird's Eye: Animal Focalization" (2001), William Nelles has distinguished between animal focalization of homodiegetic narrative and that of heterodiegetic narrative. In cases of homodiegetic narrative, the story is focalized through and narrated by the same animal agent, and the animal focalizor observes the story events from within, and speaks like a human being. For example, Julian Barnes's "The Stowaway" (1989) features a woodworm focalizor, and the narrator focalizor of Cervantes's "The Dialogue of the Dogs" (1613) is a dog. Despite the fact that both stories are focalized through animal narrators, their language styles are quite different. On the one hand, the language of "The Stowaway" fails to suggest that the story is focalized through a woodworm, as evidenced by the opening paragraph:

They put the behemoths in the hold along with the rhinos, the hippos and the elephants. It was a sensible decision to use them as ballast; but you can imagine the stench. And there was no-one to muck out. The men were overburdened with the feeding rota, and their women, who beneath those leaping fire-tongues of scent no doubt reeked as badly as we did, were far too delicate [18].

The above passage shows no sign that it is a woodworm that is presenting the fictional world. Obviously, the psychology and personality reflected in this passage are completely humans'. A woodworm's mental state should be distinctive from that of humans. However, in this story, we don't realize that we see the storyworld through the eyes of a woodworm until the last sentence: "And after all, it's not our fault for being woodworm" [18]. Such revelation creates a shocking effect which is what the author tires to achieve by equipping an insect with human thoughts. "The Dialogue of the Dogs," on the other hand, clearly shows that the story is filtered through the consciousness of a dog. Much of the story represents a dog's concerns and thoughts such as his eagerness to be free from the leash, his desire to flatter his master. What the author achieves through presenting a dog's vision is an effect of verisimilitude. Some homodiegetic narrative texts of animal focalization even juxtapose animal consciousness and human mental process. Marie Darrieussecq's Pig Tales. A Novel of Lust and Transformation (1996) is a case in point. In the story, the main focalizor, a sow, is originally a human; after its metamorphosis, it thinks as a sow does, but retains human desires, beliefs and mental capabilities.

Likewise, in heterodiegetic narrative texts, there are passages of animal focalization which reproduce animal reflectors' psychological and visionary worlds to a greater or lesser degree. The following passage from Paul Auster's Timbuktu (1999) is entirely focalized through a dog reflector:

The other dogs were up and about, barking in anticipation of the day ahead, but the best he could do was lie there in his torpor, contemplating the bollix his body had made of things. He knew that he was sick, but exactly how sick, and exactly where this sickness was taking him, he had no idea [19].

In the above passage, Auster deftly displays a dog's psychological perspective as well as its physical perspective. Such verbs as "contemplate" and "know" clearly show that the dog focalizor is reflecting. The other dogs' running about and whining forms a scene within the field of vision of the dog focalizor. In heterodiegetic narrative texts, nevertheless, animal focalization usually creates ambiguities that "are not much different than those encountered in human focalization" [20]. The so called free indirect speech in heterodiegetic narrative texts is tainted with both characters' and authorial voices. If sentences of free indirect speech are thought representations, they can be understood as either characters' thought representations or authorial reports. It is, therefore, often hard to differentiate between them. Dorrit Cohn considers this phenomenon as one of key features of narrated monologue which "casts a peculiarly penumbral light on the figural consciousness," and suspends "it on the threshold of verbalization in a manner that cannot be achieved by direct quotation" through "leaving the relationship between words and thoughts latent" [21]. Numerous thought representations of the dog focalizor in Timbuktu, for example, are in most cases undistinguishable from authorial reports. Let me, by way of illustration, quote a statement from the opening paragraph: "The cough had been inside him for over six months, and by now there wasn't a chance in hell that he would ever get rid of it" [19]. Clearly, it can be understood as an authorial report on the background of this story or the dog focalizor's reflection on his master's illness.

\section{Conclusion}

Ultimately, focalization is a key narrative concept serving as an interpretative perspective, and its evolution deserves careful study for students taking narratology courses. Scholars initially conflated focalization and narration, and it is Genette who distinguished between point of view and voice. Following Genette pioneering work on focalization, scholars of classical narratology managed to develop varied focalization theories with an emphasis on structural and linguistic features. Postclassical narratology studied 
focalization with an interdisciplinary approach, focusing on subjective reception and context. Nonhuman focalization, an important aspect of focalization study, is also a valuable interpretative tool that students can utilize to analyze narrative texts, enabling students to notice a distinctive dimension of focalization theory.

\section{References}

[1] Genette, Gérard (1980). Narrative Discourse. Trans. Jane E. Lewin. Ithaca: Cornell University Press, 186, 188, 188, 189, $189,189-190$

[2] Brooks, Cleanth, and Robert Penn Warren (1979). Understanding Fiction. $3^{\text {rd }}$ ed. Englewood Cliffs, New Jersey: Prentice-Hall, Inc., 174.

[3] Friedman, Norman. "Point of View in Fiction: The Development of a Critical Concept." PMLA 70.5 (1955): 1160-1184.

[4] Stanzel, F. K. (1984). A Theory of Narrative. Trans. Charlotte Goedsche. Cambridge: Cambridge University Press, 4-5.

[5] Lubbock, Percy (1957). The Craft of Fiction. London: Jonathan Cape, 149-150.

[6] Bal, Mieke (1997). Narratology: Introduction to the Theory of Narrative. Toronto: University of Toronto Press Incorporated, 150, 146, 148.

[7] Rimmon-Kenan, Shlomith (2005). Narrative Fiction: Contemporary Poetics. $2^{\text {nd }}$ ed. Abingdon, Oxfordshire: Taylor \& Francis e-Library, 76.

[8] Genette, Gérard (1988). Narrative Discourse Revisited. Trans. Jane E. Lewin. Ithaca: Cornell University Press, 65.

[9] Flaubert, Gustave (2004). Madame Bovary. Trans. Margaret Mauldon. New York: Oxford University Press, 57-58.
[10] Chatman, Seymour (1978). Story and Discourse: Narrative Structure in Fiction and Film. Ithaca: Cornell University Press, 151-152.

[11] Chatman, Seymour (1993). Reading Narrative Fiction. New York: Macmillan Publishing Company, 130, 134, 134.

[12] Jahn, Manfred. "Windows of Focalization: Deconstructing and Reconstructing a Narratological Concept." Style 30.2 (1996): 241-267.

[13] Jahn, Manfred. "More Aspects of Focalization: Refinements and Applications." Jahn: Homepage. N. p., 4 Mar. 2000. Web. 18 February 2016.

[14] Herman, David. "Hypothetical Focalization." Narrative 2.3 (1994): 230-253.

[15] Poe, Edgar Allan. "The Fall of the House of Usher." The Norton Anthology of Short Fiction. $3^{\text {rd }}$ ed. Ed. R. V. Cassill. New York: W. W. Norton \& Company, 1986. 1241-1257.

[16] Crane, Stephen. "The Open Boat." The Norton Anthology of Short Fiction. $3^{\text {rd }}$ ed. Ed. R. V. Cassill. New York: W. W. Norton \& Company, 1986. 335-354.

[17] Richardson, Brian (2019). A Poetics of Plot for the Twenty-First Century: Theorizing Unruly Narratives. Columbus: The Ohio State University Press, 3.

[18] Barnes, Julian (1990). A History of the World in $101 / 2$ Chapters. New York: Vintage Books, 3, 30.

[19] Auster, Paul (2000). Timbuktu. New York: Picador USA, 168, 3.

[20] Nelles, William. "Beyond the Bird's Eye: Animal Focalization." Narrative 9.2 (2001): 188-194.

[21] Cohn, Dorrit (1978). Transparent Minds: Narrative Modes for Presenting Consciousness in Fiction. Princeton: Princeton University Press, 103. 